\title{
EPISTEMOLOGICAL IMPLICATIONS OF NEUROARCHITECTURE
}

\section{Hana Samaržija}

A B S T R A C T

This article will attempt to explain how the spatial characteristics of built environments affect both the cognitive processes of producing knowledge and the epistemic quality of other doxastic states. Recent discussions in philosophy and the social sciences have been vocal about the changing dynamics of contemporary life. As clouded boundaries between labor and leisure make individuals spend most of their time in built environments, personal experiences of space, buildings, and interiors are becoming a decisive factor in self-perception and cognition. These circumstances have encouraged the advent of a new scientific field: neuro-architecture, a branch of functional design supported by neurological brain scanning technologies and the concept of neuroplasticity, the brain's capacity to change its structure along our behavior and surroundings. After articulating neuro-architecture's ambition to define spaces most suitable for promoting positive emotions, good health, and intellectual agility, the article will critically assess its epistemological implications and its potentially unfavorable impact on architectural aesthetic autonomy. This intrusion of natural sciences into the ostensibly artistic domain of architecture bears certain similarities to the tension between traditional analytic philosophy - which was preoccupied with idealized models of intellectual practices and mental processes - and scientific insights into human cognition, perhaps best illustrated by the mind-brain identity theory. 


\section{INTRODUCTION}

I will begin by locating the advent of neuro-architecture within the current intellectual climate of evidence-based scientific practices. Only after I had outlined the methodological tools and primary aims of neuro-architecture using several everyday examples, will I proceed to argue for its relevance to pressing topics in philosophy of mind and epistemology, such as, for instance, reductionism in explaining mental processes. It might be useful to note that I will, instead of focusing on the traditional epistemological value of truth, refer to epistemological discussions about the sources of knowledge, as well as the concept of mind-brain identity characteristic of debates in philosophy of mind. I will close the discussion by tempering any unjustified enthusiasm about the revolutionary potential of neuro-architecture with the distinction between (1) strict neuro-architecture, dogmatic assent with neuro-scientific research as an aesthetic lawmaker, and (2) weak neuro-architecture, a reasonable reunion of scientific findings and the existing architectural practice.

\section{NEUROARCHITECTURE AND PHILOSOPHY}

Familiarity with recent philosophical developments informs us of its uncomfortable contemporary position. The heightened institutionalization and self-referential nature of philosophy originate from the middle of the nineteenth century, when social and natural sciences were excluded from the umbrella term of philosophy. Rapid developments in neural research soon legitimized neuroscience, a new branch of cognitive sciences, as a worthy participant in traditional philosophical and psychological debates. Stripped of many of its topics and reprimanded for its insistence on abstraction, philosophy started reflecting upon empirical findings and posing questions to be answered using more scientific methods. Philosophy of mind thus tapered its abstract speculations about consciousness and opted for an approach grounded in linguistic analyses; epistemology sought help with questions regarding sensory perception, and ethics benefitted from neurological insights into the evolutionary foundations of morality. ${ }^{1}$ Neurological findings enriched familiar philosophical issues (such as the possibility of innate knowledge, the structure of the mind, interpersonal understanding, and behavioral determinism) with a desirable measure of empirical objectivity. Some inputs from the natural sciences have proven quite fruitful, frequently confirming previously arbitrary philosophical conclusions. As an example, the popular therapeutic practice of monitoring habitual behaviors through mindfulness mimics the ancient stoic concept of proairesis, the learned act of postponing reactions with the goal of separating rational choices from irrational impulses. ${ }^{2}$ Further insights into the current status 
of philosophy of mind teach us that the decision to delegate specific topics to natural sciences in no way jeopardizes the validity of philosophical research, as will be shown in the remainder of this article.

\section{NEUROSCIENCE AND ARCHITECTURE}

Philosophy is in no sense the only discipline whose autonomy has been challenged by the popularity of neuroscience. Technological developments such as functional magnetic resonance scanning (fMRI) have prompted a surge of new scientific fields informed by neuro-scientific research, including neuroeconomy, neuro-marketing and, finally, neuro-architecture. ${ }^{3}$

Within the domain of architecture, scanning neural responses to spaces has surfaced as a progressive - yet seldom practiced - method in design, urbanism, and spatial planning. It has been shown that built environments relevantly affect neural structures and learning processes. Back in the nineteenth century, father of neuroscience Ramon y Cajal made the incorrect assumption that brain cells gradually "dry out irrevocably", sentencing us to continuous decay with no prospect of regeneration. ${ }^{4}$ This fallacious argument stuck for over 100 years and was first challenged at the end of the twentieth century, when researchers studying rhesus monkeys observed their ability to grow new brain cells in response to environmental changes. As a highly efficient organ, the human brain undergoes changes to make our behavior as well-adjusted and as automatic as possible. Although genetics indeed determine the underlying outline of neural circuits, environmental settings settle whether or not we will realize this genetic potential. Seeing that spatial changes alter neural structures, which lie at the foundation of who we are and how we act, they will necessarily proceed to modify human behavior. With this in mind, new architectural paradigms and specific designer ideologies no longer seem like the idle subjects of aesthetical polemics, but become the determinants of our behavior in real social circumstances. ${ }^{5}$

So defined, the interconnection between architecture and neuroscience binds architects with two new ethical imperatives. In order to design responsibly, architects ought to be informed about (1) spatial solutions best suited for particular spaces, such as, for example, the specific manner in which study halls may encourage focus, patience, community, and student interaction, and about (2) the potentially harmful effects of excessive stylistic exhibitions on the emotional states and cognition of architectural users. Architecture is unique in its dual role of an art form and the functional aspects of creating 
physical spaces. ${ }^{6}$ Unlike other arts, it has to maintain a steady balance between aesthetic and ethical desiderata. Continued dialogue between architecture, psychology, cognitive sciences, and neuroscience might, in this sense, be a fruitful interdisciplinary platform for understanding the complex interplay of architectural specificities and human cognition. ${ }^{7}$

\section{BEGINNINGS OF ACADEMIC NEUROARCHITECTURE}

The Academy of Neuroscience for Architecture (ANFA) was founded in 2003 by architect and interdisciplinary pioneer John Eberhard. In Brain Landscape, an introductory work serving as a neuro-architectural manifesto, Eberhard recalls his architectural journey and the sources of his interest in the link between architecture and mental states. He was, we learn, initially interested in gothic sacral architecture. Surrounded by architects dismissive of excessive ornamentation and hesitant to embrace modernist design, Eberhard eventually turned to interdisciplinary approaches to architecture. These inquiries led to his collaboration with the Californian Salk Institute, where he met his future colleague, neuroscientist Fred Gage. They jointly conducted a series of experiments on mice to show how different environments can physically change our brains.

Their reflections gained momentum when recognized by the president of the American architectural society, Norman Koonce. He had heard that Jonah Salk, the virologist who had established the eponymous Salk Institute, discovered the cure for polio after experiencing a particularly refreshing architectural ambient. Frustrated by years of unsuccessful research, Salk retreated to an Assisi monastery in Umbria, Italy. Having found the cure almost the moment he had returned from Italy, he attributed his success to the "intellectually restorative
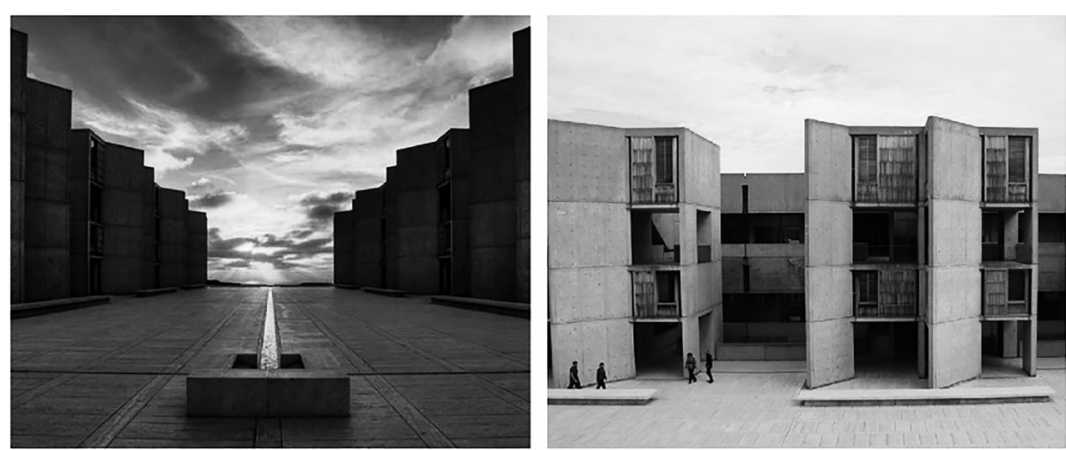

Fig. 1. Louis Kahn's Salk Institute in San Diego, California (C) Liao Yusheng (https://www.archdaily.com/61288/ad-classics-salk-institute-louis-kahn) 
environment" of the monastery. The Academy of Neuroscience for Architecture was founded in San Diego in 2003. Although it had initially retained Eberhard's focus on defining the universal environmental foundations of human cognition, gradually shifted to the specific spaces of schools, hospitals, and offices. ${ }^{8}$

\section{NEUROARCHITECTURE AND FUNCTIONAL DESIGN}

Should the neuro-architectural approach, despite its relative novelty, seem familiar, this is not a fallacious resemblance: neuro-architecture stems from the rich tradition of functional, informed and evidence-based design. ${ }^{9}$ Owing to technological limitations, these theories hinged on the questionably empirical methods offered by behavioural psychology, which had researchers monitor subjects in different architectural environments and later interview them about their experiences.

The behaviorist approach to informed design, however, soon encountered the same objections that had dethroned behavioral psychology: it could only infer questionably sound conclusions from unstructured observations. In simpler terms, a highly subjective scientist, inevitably stifled by his theoretical background, observes the behavior of a stranger, one aware she is being watched, in an artificial setting. Behavioral observations don't automatically isolate the exact spatial feature that causes a particular mental process. Once we enter a given space, we simultaneously face many vastly different architectural stimuli, and our response cannot be confidently attributed to any individual feature. Imagine, for example, someone who seems calm when sitting in an airy, naturally lit and uncomplicated space with abundant greenery. ${ }^{10}$ An
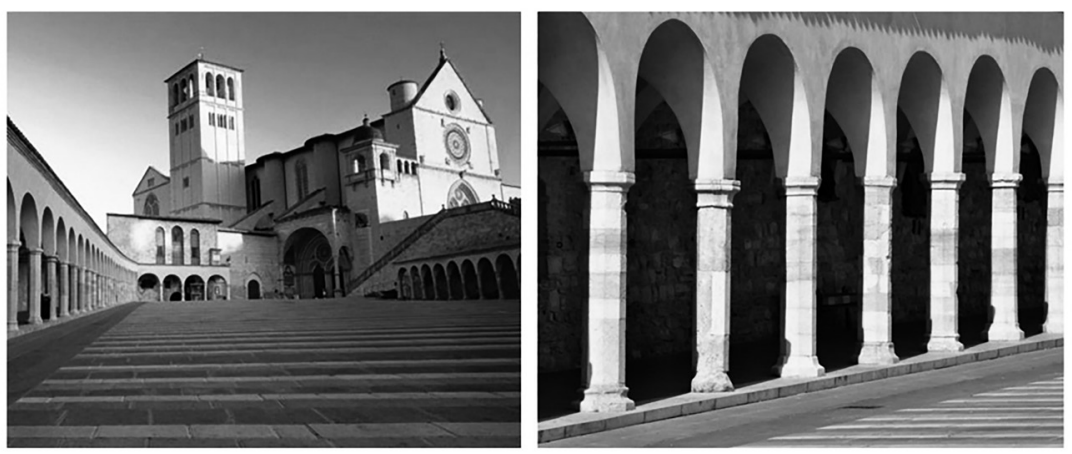

Fig. 2. Monastery of Assisi, Umbria (https://psmag.com/social-justice/corridors-of-the-mind-49051) 
observer could not determine which spatial element - the dimensions, colors, light, simplicity, plants - caused this effect, or whether a positive outcome only arises from a combination of these features. Efforts to render observations more exact by using interviews proved similarly futile, as participants seldom managed to coherently voice their experiences, and instead resorted to generic phrases borrowed from lay descriptions of architecture. Fruitful conversations with children were equally unlikely, largely due to their unfamiliarity with the conceptual vocabulary one needs to articulate emotions and insights.

Neuro-architecture provided these inquiries with required empirical accuracy, as fMRI visualizations enabled researchers to isolate the exact brain regions activated by particular architectural stimuli. ${ }^{11}$ These new technologies offered a precise and easily quantifiable way to measure physiological reactions as an alternative to biased conclusions based on observations. In early experiments, examinants wore wireless helmets that recorded their responses to buildings while enabling them to move freely through space. Much more promising is the recently developed Cave virtual reality system, where examinants are positioned in a virtual environment that perfectly stimulates different visual and auditory stimuli. ${ }^{12}$ Researchers can dynamically alter spatial characteristics and immediately note different physiological reactions to different spatial solutions, all of which correlate with easily identifiable mental processes. An accelerated heart rate, for instance, indicates heightened excitement and a stress response to some given environment. Similarly, multiple muscle contractions are a distinct symptom of stress, while muscular relaxation corresponds to comfort and security. ${ }^{13}$
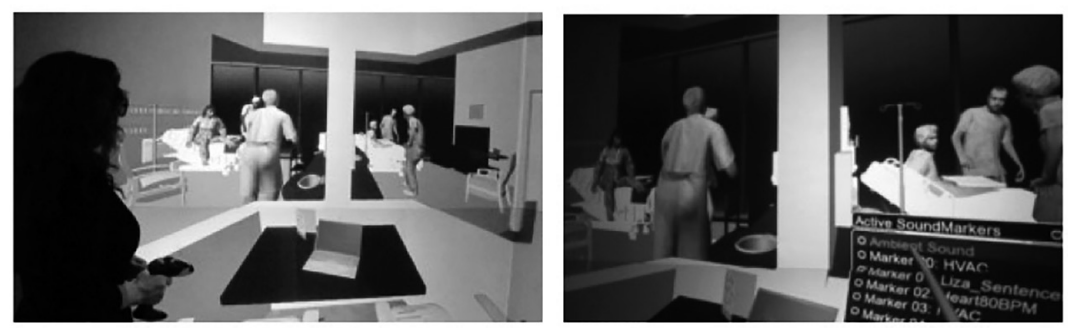

Fig. 3. CaveCAD Virtual Simulation Software (http://www.worldhealthdesign.com/Neuro-architecture.aspx) 


\section{ARCHITECTURE AS AN AGENT OF KNOWLEDGE PRODUCTION - THE NEUROARCHITECTURE OF EDUCATIONAL FACILITIES}

In 2005, ANFA conducted the first comprehensive appraisal of the way physical spaces affect student focus, attention, and cognition. Using neuro-architectural findings in educational architecture is not only a fruitful approach to improved academic performance, but entails important epistemological implications about the susceptibility of doxastic states to external conditions.

After accepting presumptions about sensible design derived from Humean folk psychology, neuro-architecture begins by (1) proposing hypotheses about the influence of environmental settings on cognition. Researchers then (2) briefly delineate their research methodology and (3) predict the exact physiological reactions that might confirm their initial assumptions. Since neuro-architecture heavily draws on psychology and architectural theory, the intermediate stage wherein research clarify their methodology is not without justification. Depending on whether a particular study intends to propose architectural resolutions or offer theoretical insights, it might put more or less emphasis on practical concerns. After (4) testing their results on real examinants, they (5) aid architects in designing more appropriate buildings. A scientist might, for example, assume that abundant natural lighting encourages focus and better short-term memory. They may then choose to use fMRI scans and saliva samples to measure the exact amounts of sleep hormones in the examinant's saliva and record brain activity in regions related to wakefulness and attention. If these experiments prove fecund, scientists might then advise architects to ensure that schools are adequately lit.
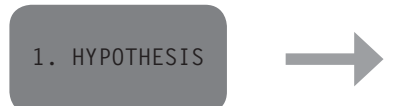

5. SUGGESTIONS FOR ARCHITECTS
3. PREDICTING

PHYSIOLOGICAL REACTIONS

4. TESTING CONCLUSIONS ON REAL EXAMINANTS

Fig. 4. Neuro-architectural research methodology 
When researching educational facilities, ANFA studied (1) wakefulness, the ability to stay alert throughout the day, (2) focus and attention, the ability to continuously engage in a specific topic of interest, (3) neurogenesis, the growth of new neurons from neural stem cells, and (4) stress reduction. It was shown that stress levels have important implications for the subject of rationality. Since the brain is a highly efficient organ, it adjusts its activities to the environment. Surroundings that incite "fight-or-flight" stress responses discourage the brain from supporting rational reasoning, located in the prefrontal lobe, and instead support automatic responses to fear. In the simplest study, scientists tested student reactions to abundant natural light. Brain scans revealed increased activity in occipital and parietal brain regions. These areas are related to focus, attention and cognition, and are known to light up during intensive learning. By testing samples of student saliva, scientists also found decreased levels of sleep hormones. Disproportionate exposure to artificial lighting or computer screens is known to disrupt the natural circadian rhythm and may cause sleep disorders. Moreover, fMRI scans show that natural lighting increases brain growth factors (BDF) which lead to the formation of new neural cells and delay cognitive decay. Once we return to student behavior and learning, it becomes evident that students exposed to natural light will be more attentive and focused, and will thus be more likely to achieve better academic performance. ${ }^{14}$

Keeping these findings in mind, the Corona Del Mar high school campus in California seems like an example of progressive practice. Designed in collaboration with ANFA itself, it was built entirely using the smooth and calming foundations of bluish steel. Even a glance reveals consistency with the mentioned research: steel barriers are abundant with holes that supply

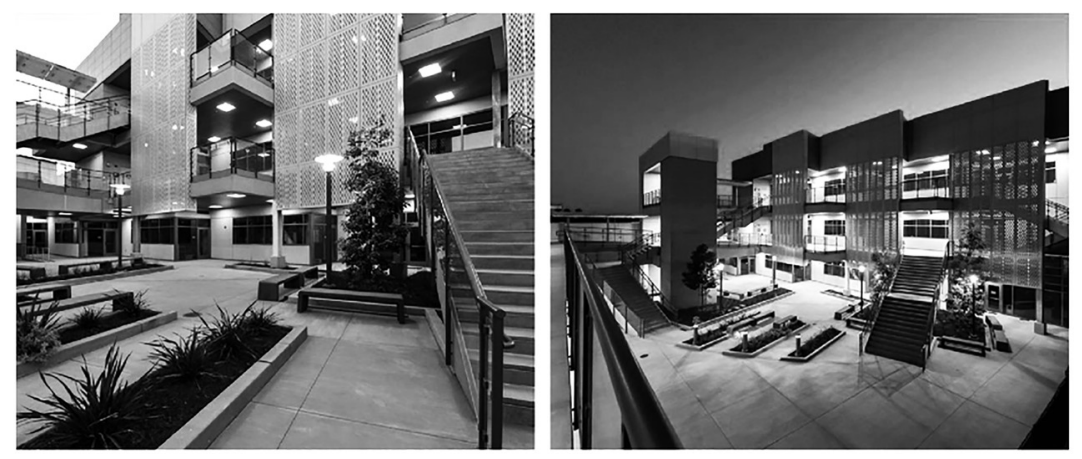

Fig. 5. Corona Del Mar High School Enclave (C) Dougherty \& Dougherty Architects (http://www.kprsinc.com/media-post/corona-del-mar-high-school-enclave-is-complete/) 
natural sunlight throughout the day. Corridors have been placed out in the open, allowing students to gaze at greenery and the courtyard while transitioning between lecture rooms. The obvious emphasis on greenery reduces stress levels in students and encourages continuous zest throughout extended study hours. All lecture halls, laboratories, and administrative units are connected by sharply marked staircases, elevators, and terraces, turning the complex into a unified and fluid spatial whole. Instead of bleak static lights, the Dougherty architectural bureau opted for warm diffused lighting that adjusts to weather conditions. Nearby parks and schoolyards contain clusters of typical Californian greenery and students are encouraged to spend breaks in the surrounding parks.

\section{NEUROARCHITECTURE, PHILOSOPHY OF MIND AND EPISTEMOLOGY}

Even though philosophers of mind held on to most of their original topics, they soon conceded that theoretical debates could not provide conclusive answers about human cognition. Since discussions about consciousness, perception, qualia and the nature of mental states proved especially tricky to resolve in purely speculative terms, philosophy accepted guidance from cognitive science, neuroscience, and evolutionary psychology. ${ }^{15}$ Philosophers such as Thomas Nagel have been fairly explicit about their stance on participation from natural sciences. Nagel has, in fact, stated that the mind-body problem and the questions of consciousness would be solved after a paradigm shift has surpassed the current explanatory gap, but held no convictions that theoretical philosophy will be the one to resolve them. ${ }^{16}$
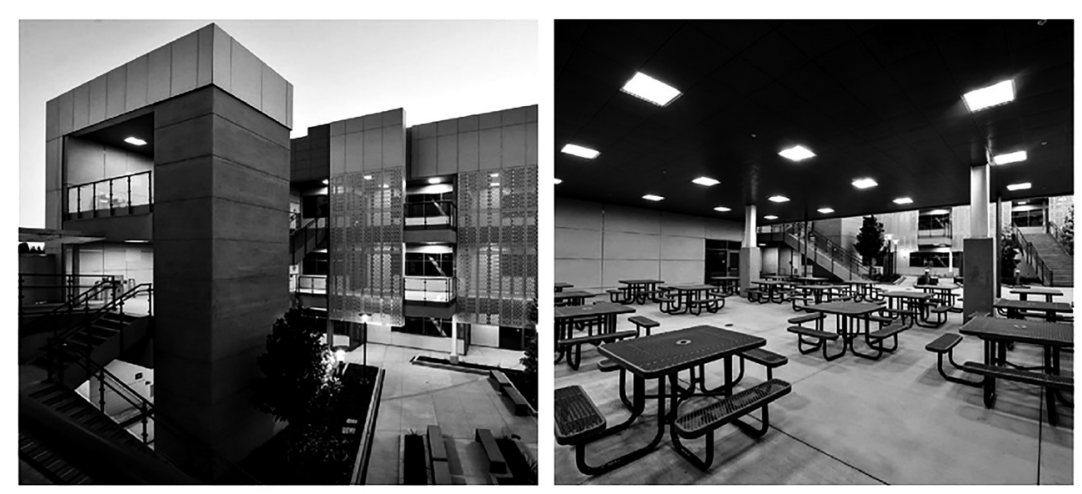

Fig. 6. Corona Del Mar High School Enclave (C Dougherty \& Dougherty Architects (http://www.kprsinc.com/media-post/corona-del-mar-high-school-enclave-is-complete/) 
Knowing that natural sciences rest on materialist theoretical foundations, they presume a certain reductionism concerning mental states. Brain scans have shown that sensed mental processes - emotions, urges, and conscious thoughts - appear in sync with underlying physical changes, which we refer to as their neural correlates. Neuroscience is, consequently, adamant in claiming that there is no significant difference between mental states and neural processes. Since behavioral cues can help us identify different mental states, it could be argued that there is a causal link between behaviors and mental states. We would claim, for example, that neural activity in an examinant's amygdala caused their aggressive behavior. However, the relationship between psychological and neural processes is, from a strictly neurological perspective, not one of causation, but of correlation or identity.

Although this recent neuro-scientific discovery has been long implicit in the philosophy of mind, terminological issues have obscured this identity. Neuroscientists, for one, assume that the correlation between mental and neural processes (i.e., the presence of an observable neural process concurrent with what a person perceives as an emotion) confirms their identity. Philosophers of mind, on the other hand, base identity relations on a different linguistic distinction. Let us consider, for example, the familiar state of tiredness. Since neuroscience can now relate the subjective experiences of, for example, reduced mental acuity and fatigue, to physical neural processes (more accurately, to reduced activity in the parietal region and the frontal lobe), it can conclude that tiredness is, essentially, the reduced activity of specific neural regions. The identity theory of mind ${ }^{17}$ holds that states and processes of the mind are identical to states and processes of the brain. Concerning the experience of pain, the identity theory would claim that pain is just a brain process, rather than merely correlated with a brain process. A balanced answer, however, might be found in the philosophical work of Ludwig Wittgenstein. ${ }^{18}$ In Philosophical Investigations, Wittgenstein rejected the mind-body problem as illusory. He argued that inquiring about the dynamics between mental and neural processes is, in effect, fallacious. Instead, we should simply accept that human experience can be described in different ways: using either the psychological lexis of emotions or the biological vocabulary of natural sciences. ${ }^{19}$ According to Wittgenstein, illusory problems arise when one tries to explain a phenomenon by using an inappropriate vocabulary. Seeking mental states in the brain would be misguided, and attributing thoughts and emotions to the brain is, consequently, a category error or a fallacy of reasoning. 


\section{STRICT AND WEAK NEUROARCHITECTURE}

To sum up, certain aspects of neuro-architecture seem to be philosophically justified. Even so, this conclusion in no way implies that neuroscience ought to be given primacy in all architectural undertakings. Architecture is specific in its dependence on both aesthetic and functional criteria. An exaggerated emphasis on the artistic aspects of architecture, however, makes architects perceive scientific inputs as constraints on their creative freedom. We might recall that neuroscientific findings are generally congruent with the folk psychology that had informed traditional architecture, and neuro-architectural advice should too be treated as something already implicit in architectural solutions. Brain scans have yet to reveal an unanticipated reaction to architectural stimuli that has gone entirely overlooked. Benefits of neuro-architecture lie in its ability to isolate particular architectural solutions which cause particular behaviors, so that we could deliberately use them in appropriate contexts. Schools and universities would, for instance, avail from avoiding architectural decisions that thwart attention and focus by producing automatic stress responses.

We might benefit from a distinction between (1) strict and (2) weak applications of neuro-architecture. The first category, a rigid approach that treats scientific findings as a replacement on the architect's knowledge, experience, and research, is not an acceptable stance. On the other hand, we could use the weaker model to assess which buildings should be defined by their function. In the discussed example of academic institutions, it seems that schools and universities derive significance from their purpose - the aims of producing knowledge and encouraging epistemic virtue - rather than their form, albeit all activities benefit from pleasant surroundings. An architect's conscious choice to disrespect scientific findings by building dimly lit and visually overwhelmingly schools might be more damaging to their function than adherence to data would hinder the architect's aesthetic autonomy. 
For detailed arguments, see see Alvin Goldman, Liaisons: Philosophy Meets the Cognitive and Social Sciences (Massachusetts: MIT Press, 1992), 154-157.

A similar claim, pertaining to both stoic and Buddhist thought, can be found in Robert Wright, Why Buddhism is True (New York: Simon and Schuster, 2017), 33-35.

John Eberhard, Brain Landscape: The Coexistence of Neuroscience and Architecture (London: Oxford University Press, 2008).

Quoted from John Eberhard, Brain Landscape: The Coexistence of Neuroscience and Architecture (London: Oxford University Press, 2008): xiii-xiv.

An early articulation in Gerald Edelman and Giulio Tononi, A Universe of Consciousness: How Matter Becomes Imagination (New York: Basic Books, 2001).

Saul Fisher, "Philosophy of Architecture", The Stanford Encyclopedia of Philosophy (Winter 2016 Edition), Edward N. Zalta (ed.), https://plato.stanford.edu/archives/win2016/entries/architecture/. 
Justin Hollander and Ann Sussman, Cognitive Architecture: Designing for How We Respond to the Built Environment (London: Routledge, 2009).

DeFanti et al, "The StarCAVE, A third-generation CAVE and virtual reality OptiPortal," Future generation computer systems/The international journal of grid computing: Theory, methods and applications, Elsevier B.V. 25(2):169-178.

Eve Edelstein and Eduardo Macagno, "Form Follows Function: Bridging Neuroscience and Architecture," Sustainable Environmental Design in Architecture (2011): 27-41.

R. Guenther, "Sustainable architecture for health," HERD (4): 3-9

Eve Edelstein, "The effects of colour and light." World Health Design 2 (2007): 57-61

Antonio Damasio, The Feeling of What Happens; Body and Emotion in the Making of Consciousness (Belmont: Cengage Learning Inc, 2000)

Thomas Nagel, Mind and Cosmos: Why the Materialist Neo-Darwinian Conception of Nature is Almost Certainly False (Oxford: Oxford University Press, 2012)

J. J. C. Smart, “The Mind/Brain Identity Theory”, The Stanford Encyclopedia of Philosophy (Spring 2017 Edition), Edward N. Zalta (ed.), https://plato.stanford.edu/archives/spr2017/entries/mindidentity/. (Summer 2018 Edition), Edward N. Zalta (ed.), https://plato.stanford.edu/archives/sum2018/ entries/wittgenstein/.

Ludwig Wittgenstein, Philosophical Investigations, trans. G.E.M. Anscombe (Chicester: WileyBlackwell, 2016). 
Biletzki, Anat and Matar, Anat. "Ludwig Wittgenstein", The Stanford Encyclopedia of Philosophy (Summer 2018 Edition), Edward N. Zalta (ed.)

Damasio, Antonio. The Feeling of What Happens; Body and Emotion in the Making of Consciousness. Belmont: Cengage Learning Inc, 2000.

DeFanti, T.A., Dawe, G., Sandin, D.J., Schulze, J.P., Otto, P., Girado, J., Kuester, F., Smarr, L., Rao, R., "The StarCAVE, A third-generation CAVE and virtual reality OptIPortal." Future generation computer systems/The international journal of grid computing: Theory, methods and applications, Elsevier B.V. 25(2):169-178. DOI: 10.1016/j.future.2008.07.015

Eberhard, John. Brain Landscape: The Coexistence of Neuroscience and Architecture. London: Oxford University Press, 2008.

Edelman, Gerald and Tononi, Giulio. A Universe of Consciousness: How Matter Becomes Imagination. New York: Basic Books, 2001.

Edelstein Eve. "The effects of colour and light." World Health Design 2 (2007): 57-61.

Edelstein, Eve. "Evidence for sustainable design that benefits human health and performance." In City Center Development Corps Best Practices in Urban Sustainability, 2008.

Edelstein, Eve and Macagno, Eduardo. "Form Follows Function: Bridging Neuroscience and Architecture." Sustainable Environmental Design in Architecture (2011): 27-41.

Finger, Stanley. "Chapter 13: Santiago Ramón y Cajal. From nerve nets to neuron doctrine." In Minds behind the brain: A history of the pioneers and their discoveries. New York: Oxford University Press, 2000.

Fisher, Saul. "Philosophy of Architecture", The Stanford Encyclopedia of Philosophy (Winter 2016 Edition), Edward N. Zalta (ed.)

Guenther, R. 2009, “Sustainable architecture for health.” HERD (4): 3-9.

Hollander, Justin and Sussman, Ann. Cognitive Architecture: Designing for How We Respond to the Built Environment. London: Routledge, 2009.

Goldman, Alvin. Liaisons: Philosophy Meets the Cognitive and Social Sciences, Massachusetts: MIT Press, 1992.

Nagel, Thomas. Mind and Cosmos: Why the Materialist Neo-Darwinian Conception of Nature is Almost Certainly False. Oxford: Oxford University Press, 2012.

Putnam, Hilary. The Threefold Cord: Mind, Body, and World, New York: Columbia University Press, 2000.

Smart, J.J.C. "Sensations and Brain Processes.” Philosophical Review 68 (1956): 141-156.

Smart, J. J. C. "The Mind/Brain Identity Theory", The Stanford Encyclopedia of Philosophy (Spring 2017 Edition), Edward N. Zalta (ed.)

Wittgenstein, Ludwig. Philosophical Investigations, New York: Macmillan, 1954.

Wright, Robert. Why Buddhism is True, New York: Simon and Schuster, 2017.

Quine, W.V.O. 1969. "Epistemology Naturalized.” In Epistemology: An Anthology, edited by Sosa, E. and Kim, J. Chicester: Wiley-Blackwell, 2004.

Quine, W.V.O. Word and Object, Cambridge, MA: MIT Press, 1960.

Zeisel, John. Inquiry by Design: Environment/Behavior/Neuroscience in Architecture, Interiors, Landscape, and Planning, New York: WW Norton \& Co, 2006. 
utkane u asocijativni, oscilirajući tok misli, često komentarušući urbanog šetača kao glumca u kapitalističkom društvu. Za razliku od toga, Niče smatra da doživljaj arhitektonskog prostora može biti sagledan kao sveobuhvatna sinteza unutrašnjeg života i spoljašnjeg iskustva, tj. preplitanje misli i pokreta, udomljujući (pomirujući) novu kreativnu dispoziciju sa stanjem svesti.

KLJUČNE REČI: FRIDRIH NIČE, VALTER BENJAMIN, FLANEUR, ATMOSFERA, URBANI PEJZAŽ, METROPOLA

\section{EPISTEMOLOŠKE IMPLIKACIJE NEUROARHITEKTURE}

\section{Hana Samaržija}

Ovaj rad će pokušati da objasni kako prostorne karakteristike izgrađenih okruženja utiču i na kognitivne procese proizvodnje znanja i epistemički kvalitet drugih logika ubeđenja. Skorije diskusije u filozofiji i društvenim naukama eksplicitno govore o promenjivoj dinamici savremenog života. Kako zamagljene granice između rada i slobodnog vremena primoravaju pojedince da utroše najveći deo svog vremena u izgrađenim okruženjima, lična iskustva prostora, objekata i enterijera postaju odlučujući faktor u samo-percepciji i spoznaji. Ove okolnosti su ohrabrile dolazak nove naučne oblasti: neuroarhitekture, ogranka funkcionalnog dizajna podržanog tehnologijom neurološkog skeniranja mozga i konceptom neuroplastičnosti, odnosno kapaciteta mozga da promeni svoju strukturu paralelno sa našim ponašanjem i okolinom. Ovaj rad nakon razmatranja ambicija neuroarhitekture da definiše najpoželjnije prostore po kriterijumu pozitivnih emocija, dobrog zdravlja, i intelektualne krepkosti, kritički će proceniti svoje epistemološke implikacije i njen potencijalno nepovoljan uticaj na arhitektonsku estetsku autonomiju. Ovaj upliv prirodnih nauka u prividno artistički domen arhitekture podseća nas na razlike između tradicionalnih analitičkih filozofija - koje su se bavile idealizovanim modelima intelektualnih i mentalnih procesa - i uvidom nauke u ljudske spoznaje, možda najbolje ilustrovana teorijom identiteta uma-mozga.

KLJUČNE REČI: NEUROARHITEKTURA, EPISTEMOLOGIJA, SPOZNAJA, UM-MOZAK IDENTITET, FILOZOFIJA UMA

\section{PREDSTAVLJANJE FRAGMENTARNOG U MODERNOJ ARHITEKTURI}

\section{Adria Daraban}

Pojam fragmentarnog u filozofskim i umetničkim diskursima obeležava početak moderne estetike i njihovo odvajanje od koncepta celine. Ovaj rad ilustruje moguća rezonantna polja oko pojma fragmentarnog u arhitekturi koji postavlja pitanja: Može li arhitektura biti oblik izražavanja savremenog stanja fragmentarnog? Da li se pojam fragmenta razvija u arhitekturi na sličan način kao i u oblastima vizuelne umetnosti, filozofije i književnosti, ili je fragment u arhitekturi sveden isključivo na oblik prezentovanja preseka? Može li se fragmentarno definisati kao pojam uslovljen vremenom i tako osloboditi od uobičajenog tumačenja pojma kao slike o isečku?

KLJUČNE REČI: FRAGMENT, HANS ŠARUN, AVANGARDNA ARHITEKTURA U NEMAČKOJ, NEMAČKI ROMANTIZAM, OGIST RODEN, FUTURIZAM

\section{KOLATERALNA LEPOTA: NICEOVA RAZMIŠLJANJA 0 ARHITEKTURI}

\section{Mirza Vranjaković}

Sa svojim tumačenjem apolonijskog i dionizijskog stanja u psihologiji, Niče (Nietzsche) je pokušavao da poveže eminentne dihotomije svoje ere - razum i instinkt, nauku i metafiziku, iskustvo i promišljanje, znanje i inspiraciju, pojavnost i celinu, red i haos. Kroz ovaj dualizam, on se kritički osvrće na celokupno nasledje zapadnjačke kulture. Predmetni rad analizira nekolicinu Ničeovih aforizama koji su direktno ili indirektno odnose na "umetnost izgradnje". Kroz aforizme, Niče je prizivao ideju nove arhitekture koja će se usprostaviti idealu zgrade devetnajstog veka: arhitektura ne idealizuje, ona nije samo pojava, već je izgrađena u duhu svog vremena, i navodi da se u nju uselimo, i na kraju, u arhitekturi lepota nije kraj već sredstvo za postizanje cilja. 